\title{
Relationship Between Ethanol Intake and Insulin Sensitivity Metabolism in Men with no Comorbidities: A Systematic Review
}

\author{
Relación Entre la Ingesta de Etanol y el Metabolismo de la Sensibilidad \\ a la Insulina en Hombres sin Comorbilidades: Una Revisión Sistemática
}

\author{
Cristian Sandoval ${ }^{1,2} ;$ Christian Herrera $^{1} ;$ Mabel Schulz $^{1} \&$ Bélgica Vásquez $^{3}$
}

\begin{abstract}
SANDOVAL, C.; HERRERA, C.; SCHUlZ, M. \& VÁSQUEZ, B. Relationship between ethanol intake and insulin sensitivity metabolism in men with no comorbidities: A systematic review. Int. J. Morphol., 39(3):829-838, 2021.

SUMMARY: The association of alcohol consumption with type 2 diabetes has been explained by increased insulin sensitivity, anti-inflammatory effects, or effects of adiponectin. The aim was to launch a consistent relation between alcohol intake and insulin sensitivity. Several databases (MEDLINE, EMBASE, Scopus and Web of Science) were searched from 1990 to April 2020 for studies in English, using MeSH terms and text words involving to alcohol consumption and insulin sensitivity. Protocol registered on PROSPERO CRD42020205107. A total of seven original articles were analyzed, where four collected data through cross-sectional study, two papers with randomized crossover design, and one used a non-randomized study. The protective effect of moderate alcohol consumption on type 2 diabetes has been described, where an improvement on insulin levels has been shown in adults between 26.5-57 years old. Our research shows that alcohol effects on blood insulin levels could vary depending of the type of alcoholic drink ingested; and that alcohol intake increased leptin and adiponectin levels, suggesting that alcohol consumption may increase glucose catabolism promoting insulin sensitivity via leptin and adiponectin. However, original studies should consider time of exposure, age, dosage, ethnicity, and alcohol type in order to conclude right affirmations.
\end{abstract}

KEY WORDS: Alcohol drinking; Diabetes mellitus; Epidemiology; Insulin; Humans.

\section{INTRODUCTION}

Ethanol ranks first on the list of abused drugs in many parts of the world. Alcohol drinking is a chronic disease, that affects around $10 \%$ of the world population (Hedge et al., 2000). It has been reported that alcohol misuse and dependency occupy third place in the risks to human health in the world (World Health Organization, 2011; Sandoval et al., 2017).

Ethanol is harmful to the human body, able to cause toxicity and death when ingested in excessive amounts. Ethanol metabolism produces alcoholic fatty liver, alcoholic hepatitis or cirrhosis (García Gutiérrez et al., 2004; Arias, 2005), chronic pancreatitis and/or atrophy of the gray and white matter of the frontal lobes of the brain and cerebellum and limbic structures (Mukamal, 2004). Likewise, epidemiological studies suggest that reduced levels of folate in the body increase the risk of various types of cancer, including: upper respiratory and digestive tract, lung, esophagus, stomach, colon, rectum, prostate and breasts (Kim, 1999; 2004).

According to the American Diabetes Association, it is characterized by the destruction of insulin-producing cells and glucagon-producing cells. In fact, the histological findings show fibrosis, atrophy of the pancreatic acini, chronic inflammation, distortion of the pancreatic ducts with areas of stenosis and characteristic destruction of insulinproducing cells ( $\beta$ cells) and glucagon-producing cells ( $\alpha$ cells) (Witt et al., 2007). However, epidemiological data has shown positive effects to alcohol drinking when any kind of alcoholic drink it is swallowing from light-to-moderate levels, showing a reduction in mortality, due primarily to a reduced risk of coronary heart disease (Rimm et al., 1991; Doll et al., 1994; Criqui, 1996; Kannel \& Ellison, 1996; Doll, 1997; Buemann et al., 2002; Klatsky et al., 1992; Furuya et al., 2003).

\footnotetext{
${ }^{1}$ Departamento de Ciencias Preclínicas, Facultad de Medicina, Universidad de la Frontera, Temuco, Chile.

${ }^{2}$ Escuela de Tecnología Médica, Facultad de Salud, Universidad Santo Tomás, Los Carreras 753, Osorno, Chile.

${ }^{3}$ Facultad de Ciencias de la Salud, Universidad de Tarapacá, Iquique, Chile.

Funding: DIUFRO Nº DI20-0003 Project, Universidad de La Frontera, Chile.
} 
It is not clear how ethanol affects those parameters; however, some reports suggest that light-to-moderate drinking of alcohol improving insulin sensitivity, characterized by relatively low plasma insulin levels, which are paradoxically effective enough to increase glucose uptake and to improve the profile of plasma lipids and lipoproteins (Facchini et al., 1997; Lazarus et al., 1997; van de Wiel, 1998; Furuya et al.; Yokoyama, 2011).

On the other hand, the association of alcohol consumption with type 2 diabetes (T2DM) may be explained by increased insulin sensitivity, anti-inflammatory effects, or effects of adiponectin (Schrieks et al., 2015). While some studies indicate that light-to-moderate alcohol intake is associated with enhanced insulin sensitivity, the results are varied. For example, while one study showed that insulin levels decreased with higher alcohol consumption (Kannel \& Ellison); other found a U-shaped relation with moderate drinkers having the lowest insulin concentration (Facchini et al.).

Since these controversial observations have not been decoded to date and the studies leave some gaps in the complete understanding of the association of light-to-moderate alcohol consumption and insulin sensitivity (Kiechl et al., 1996), the objective of this systematic review was to establish a reliable relation between alcohol intake and insulin sensitivity.

Up to date, there have been no systematic reviews of quantitative studies to update health promotion programs and to fight against the progress of metabolic diseases. Quantitative studies can provide effectiveness evidence and relevant clinical information. To better understand the relationship between alcohol consumption and insulin sensitivity, the specific question addressed in this systematic review is: Could the alcohol intake enhance the insulin sensitivity in men between 15 and 60 years with no comorbidities?

\section{MATERIAL AND METHOD}

A systematic review of quantitative researches studying the relationship between ethanol intake and insulin sensitivity in men with no comorbidities was realized. The protocol is registered on PROSPERO database, CRD42020205107 (Sandoval et al., 2020). The review was informed according to PRISMA (Table I) (Moher et al., 2009).

\section{Search strategy and selection criteria}

Search strategy: Multiple databases (MEDLINE, EMBASE, Scopus and Web of Science) were searched from 1990 to April 2020 for original articles, primary quantitative studies in English, using MeSH terms ("alcohol intake" AND "insulin sensitivity" AND "humans") and text words relating to alcohol intake and insulin sensitivity to the research question. The searches were part of broader searches for a series of reviews covering a range of health parameters, such biochemical and metabolic analysis. Additionally, the reference lists of included studies and relevant reviews were searched.

Types of study and design: The specific inclusion criteria were: 1. primary quantitative studies or mixed methods studies with a quantitative component (using descriptive or inferential statistics methods, with parametric or nonparametric methods), reporting dosage or timing of alcohol intake, and insulin profile and; 2. studies in English. Research studies were excluded if they: 1. systematic reviews; 2. conference abstracts; 3 . editor letters; 4 . were not an original published in full; 5 . did not provide or specify numerical data; 6. studies realized just in women; and 7. studies focused on treatment of alcohol dependence or without biochemical parameters were excluded.

Population: Men aged between 15 and 60 years old, living in the community; including healthy participants with no pre-conditions for later ill health such as high blood pressure, high cholesterol, overweight or obese, impaired cognitive function and functional limitations. People over 60 years old were excluded to present frequently chronic diseases. In addition, people on medication or studies that primarily focused on populations with ill health were excluded.

Identification of relevant studies: two reviewers screened titles, abstracts and papers for inclusion. Differences between reviewers' results were resolved by discussion with another reviewer.

\section{Quality assessment/risk of bias}

Methodological quality was assessed using NICE methodology for quantitative studies by one reviewer and checked for accuracy by a second reviewer (National Institute for Health and Care Excellence, 2012). Differences between reviewers were resolved by discussion. One study was excluded on the basis of quality (Nogueira et al., 2014).

\section{Data extraction and synthesis}

Data relating to population and study characteristics of the included studies were extracted by one reviewer (CS) and checked by another reviewer $(\mathrm{CH})$ (Table II).

To identify information relevant to variables involved in insulin sensitivity during alcohol drinking in healthy 
SANDOVAL, C.; HERRERA, C.; SCHULZ, M. \& VÁSQUEZ, B. Relationship between ethanol intake and insulin sensitivity metabolism in men with no comorbidities: A systematic review. Int. J. Morphol., 39(3):829-838, 2021.

Table I. PRISMA Checklist.

\begin{tabular}{|c|c|c|c|}
\hline Section/topic & $\#$ & Checklist item & Reported on page \# \\
\hline \multicolumn{4}{|c|}{ TITLE } \\
\hline \multicolumn{3}{|r|}{ ABSTRACT } & Title, abstract and text \\
\hline Structured summary & 2 & $\begin{array}{l}\text { Provide a structured summary including, as applicable: background; objectives; } \\
\text { data sources; study eligibility criteria, participants, and interventions; study } \\
\text { appraisal and synthesis methods; results; limitations; conclusions and implications } \\
\text { of key findings; systematic review re gistration number. }\end{array}$ & $\begin{array}{l}\text { Abs tract, protocol registration refere nced in text; } \\
\text { synthe sis methods described in text due to lack of } \\
\text { space in abstract. }\end{array}$ \\
\hline \multicolumn{4}{|c|}{ INTRODUCTION } \\
\hline Rationale & 3 & Describe the rationale for the review in the context of what is already known. & Background \\
\hline Objectives & 4 & $\begin{array}{l}\text { Provide an explicit statement of questions being addressed with reference to } \\
\text { participants, interventions, comparisons, outcomes, and study design (PICOS). }\end{array}$ & Search strategy and selection criteria \\
\hline \multicolumn{4}{|c|}{ MATERIAL AND METHOD } \\
\hline Protocol and registration & 5 & $\begin{array}{l}\text { Indicate if a review protocol exists, if and where it can be accessed (e.g., Web } \\
\text { address), and, if available, provide registration information including registration } \\
\text { number. }\end{array}$ & Protocol registration under review \\
\hline Eligibility criteria & 6 & $\begin{array}{l}\text { Specify study characteristics (e.g., PICOS, length of follow-up) and report } \\
\text { characteristics (e.g., years considered, language, publication status) used as } \\
\text { criteria for eligibility, giving rationale. }\end{array}$ & Search strategy and selection criteria \\
\hline Information sources & 7 & $\begin{array}{l}\text { Describe all information sources (e.g., databases with dates of coverage, contact } \\
\text { with study authors to identify additional studies) in the search and date last } \\
\text { searched. }\end{array}$ & Search strategy and selection criteria \\
\hline Search & 8 & $\begin{array}{l}\text { Present full electronic search strategy for at } 1 \text { east one database, including any } \\
\text { limits used, su ch that it could be repeated. }\end{array}$ & Figure 1 \\
\hline Study selection & 9 & $\begin{array}{l}\text { State the process for selecting studies (i.e., screening, eligibility, included in } \\
\text { system atic review, and, if applicable, included in the meta-analysis). }\end{array}$ & Search strategy and selection criteria and Figure 1 \\
\hline Data collection process & 10 & $\begin{array}{l}\text { Describe method of data extraction fro } \mathrm{m} \text { reports (e.g., piloted forms, } \\
\text { independently, in duplicate) and any processes for obtaining and confirming data } \\
\text { from investigators. }\end{array}$ & Data extraction and synthesis \\
\hline Data items & 11 & $\begin{array}{l}\text { List and define all variables for which data were sought (e.g., PICOS, funding } \\
\text { sources) and any assumptions and simplifications made. }\end{array}$ & $\begin{array}{l}\text { Selection criteria/ data extraction an d synthesis and } \\
\text { Table } 2 / \text { Table } 3\end{array}$ \\
\hline $\begin{array}{l}\text { Risk of bias in individual } \\
\text { studies }\end{array}$ & 12 & $\begin{array}{l}\text { Describe methods used for assessing risk of bias of individual studies (including } \\
\text { specification of whether this was done at the study or outcome level), and how } \\
\text { this information is to be used in any data synthesis. }\end{array}$ & Table IV \\
\hline Summar y measures & 13 & State the principal summary measures (e.g., risk ratio, difference in means). & $\begin{array}{l}\text { Selection criteria/ data extraction an d synthesis and } \\
\text { Table } 2 / \text { Table } 3\end{array}$ \\
\hline Synthesis of results & 14 & $\begin{array}{l}\text { Describe the methods of handling data and combining results of studies, if done, } \\
\left.\text { including measures of consistency (e.g., } \Gamma^{2}\right) \text { for each meta-analysis. }\end{array}$ & Selection criteria/ data extraction an d synthesis \\
\hline & & & Meta-analysis not relevant for mixed studies \\
\hline Risk of bias across studies & 15 & $\begin{array}{l}\text { Specify any assessment of risk of bias that may affect the cumulative evidence } \\
\text { (e.g., publication bias, selective reporting within studies). }\end{array}$ & Text, quality assessment \\
\hline Additional analyses & 16 & $\begin{array}{l}\text { Describe methods of additional analyses (e.g., sensitivity or subgroup analyses, } \\
\text { meta-regression), if done, indicating which were pre-specified. }\end{array}$ & N/A \\
\hline \multicolumn{4}{|c|}{ RESULTS } \\
\hline Study selection & 17 & $\begin{array}{l}\text { Give numbers of studies screened, assessed for eligibility, and included in the } \\
\text { review, with reasons for exclusions at each stage, ideally with a flow diagram. }\end{array}$ & Figure 1 \\
\hline Study characteristics & 18 & $\begin{array}{l}\text { For each study, present characteristics for which data were extracted (e.g., study } \\
\text { size, PICOS, follow-up period) and provide the citations. }\end{array}$ & Table II \\
\hline Risk of bias within studies & 19 & $\begin{array}{l}\text { Present data on risk of bias of each study and, if available, any outcome level } \\
\text { assessment (see item 12). }\end{array}$ & Table IV \\
\hline Results of individual studies & 20 & $\begin{array}{l}\text { For all outcomes considered (benefits or harms), present, for each study: (a) } \\
\text { simple summary data for each intervention group (b) effect estimates and } \\
\text { confidence intervals, ideally with a forestplot. }\end{array}$ & $\mathrm{N} / \mathrm{A}$ \\
\hline Synthesis of results & 21 & $\begin{array}{l}\text { Present results of each meta-an alysis done, including confidence intervals and } \\
\text { measures of consistency. }\end{array}$ & N/A \\
\hline Risk of bias across studies & 22 & Present results of any assessment of risk of bias across studies (see Item 15). & Text, quality assessment/ Table IV \\
\hline Additional analysis & 23 & $\begin{array}{l}\text { Give results of additional analyses, if done (e.g, sensitivity or subgr oup analyses, } \\
\text { meta-regression [see Item 16]). }\end{array}$ & N/A \\
\hline \multicolumn{4}{|c|}{ DISCUSSION } \\
\hline Summar y of evidence & 24 & $\begin{array}{l}\text { Summarize the main findings including the strength of evidence for each main } \\
\text { outcome; consider their relevance to key groups (e.g., healthcare providers, users, } \\
\text { and policy makers). }\end{array}$ & Discussion \\
\hline Limitations & 25 & $\begin{array}{l}\text { Discuss limitations at study and outcome level (e.g., risk of bias), and at review- } \\
\text { level (e.g., incomplete retrieval of identified research, reporting bias). }\end{array}$ & Discussion \\
\hline Conclusions & 26 & $\begin{array}{l}\text { Provide a general interpretation of the re sults in the context of other evidence, and } \\
\text { implications for future r esearch. }\end{array}$ & Discussion \\
\hline \multicolumn{4}{|c|}{ FUNDING } \\
\hline Funding & 27 & $\begin{array}{l}\text { Describe sources of funding for the systematic review and other support (eg., } \\
\text { supply of data); role of funders for the systematic review. }\end{array}$ & Financial Disclosure section \\
\hline
\end{tabular}


Table II. Characteristics of included studies.

\begin{tabular}{lcccl} 
Study & Country & Age (years) & \multicolumn{1}{c}{ Population, setting } & \multicolumn{1}{c}{ Study objective } \\
\hline Nogueira & BR & $29.5 \pm 3$ & $\mathrm{~N}=10$ healthy male with BMI values \\
of al., 2014 & & & $\begin{array}{l}\text { To investigate the effects of four } \\
\text { different types of alcoholic beverage, } \\
\text { namely Pilsen-type beer, red wine } \\
\text { (Cabemet Sauvignon), Scotch whisky }\end{array}$ \\
& & & $\begin{array}{l}\text { and cachaça, on certain biochemical } \\
\text { parameters (blood alcohol } \\
\text { concentration, plasma insulin } \\
\text { concentration, and plasma glucose }\end{array}$ \\
& & & concentration) in male and female \\
& & & volunteers.
\end{tabular}

\begin{tabular}{|c|c|c|c|}
\hline $\begin{array}{l}\text { Flanagan } \\
\text { et al., } 2002\end{array}$ & UK & $21-41$ & $\begin{array}{l}\mathrm{N}=21 \text { healthy subjects, in a } \\
\text { randomized crossover design, either } \\
\text { received three units of ethanol ( } 1 \text { unit } \\
=8 \mathrm{~g} \text { ethanol) daily for } 1 \text { week or } \\
\text { abstained from ethanol. }\end{array}$ \\
\hline $\begin{array}{l}\text { Beulens et } \\
\text { al., } 2008\end{array}$ & NL & $18-35$ & $\begin{array}{l}\mathrm{N}=20 \text { healthy, lean (BMI }=18.5-25 \\
\left.\mathrm{~kg} / \mathrm{m}^{2}\right) ; \quad \text { or o verweight } \\
\left(\mathrm{BMI}>27 \mathrm{~kg} / \mathrm{m}^{2}\right)\end{array}$ \\
\hline $\begin{array}{l}\text { Funayama } \\
\text { et al., } 2017\end{array}$ & JP & $25-50$ & $\begin{array}{l}\mathrm{N}=8 \text { non-obese Japanese men with } \\
\text { mildly elevated fasting plasma } \\
\text { glucose and drinking habits } \\
\text { (mean f requency; } 5.6 \pm 2.5 \\
\text { times/week, mean alcohol } \\
\text { consumption; } 32.1 \pm 20.0 \mathrm{~g} / \mathrm{day} \text { ). }\end{array}$ \\
\hline $\begin{array}{l}\text { Goude } e t \\
\text { al., } 2002\end{array}$ & SE & 58 & $\begin{array}{l}\mathrm{N}=391 \text { healthy men and not } \\
\text { undergoing any treatment with } \\
\text { cardiovascular drugs. }\end{array}$ \\
\hline
\end{tabular}

Nogueira BR $20-57 \quad \mathrm{~N}=15$ men, healthy non-smokers free et al., 2017

Uribe $e t \quad$ US $\quad 46 \pm 11$

of liver disease or any other disorder that could alter the metabolism of alcohol, with a habitual alcohol intake classified as low (0.1 to $9.9 \mathrm{~g}$ of ethanol per d) to moderate (10 to $30 \mathrm{~g}$ of ethanol per day), as evaluated by means of an appropriate food frequency questionnaire.

$\mathrm{N}=25$ nondiabetic, noncirrhotic Latino adults without or with $\mathrm{HCV}$ underwent 3-day metabolic assessment before and after prescription of 6 weeks of moderate
To examine the effect of short-term alcohol consumption on the metabolic control of glucose tolerance.

To investigate the effect of moderate alcohol consumption on adipokines and insulin sensitivity.

To investigate the effect of 1-week alcohol abstinence on hepatic insulin sensitivity and FPG in non-obese Japanese men.

To examine whether the metabolic syndrome (as recently defined), components of this syndrome and smoking are associated with alcohol consumption.

To compare the effects of consuming $\mathrm{AB}$ and $\mathrm{NAB}$ on the biochemical blood parameters.

To investigate the impact of moderate alcohol discontinuation on insulin sensitivity and secretion in Latinos using direct measurement.

alcohol discontinuation.

RCT: randomized controlled trial; AB: Alcoholic beer; BMI: Body Mass Index; FPG: Fasting plasma glucose; HCV: Hepatitis C Virus; NAB: Non-alcoholic beer.

humans, one researcher (MS) examined the results and discussion sections of each text, to identify data relating to insulin sensitivity and drinking patterns. The text was then further examined and re-organized into themes (Table III). Further interpretation and analysis were then conducted to develop potential alcohol prevention or reduction strategies identified from the texts.

\section{RESULTS AND DISCUSSION}

The Fig. 1 illustrates the flow chart for the study selection process from seven papers were identified (Flanagan et al., 2002; Goude et al., 2002; Uribe et al., 2004; Nogueira et al., 2014; Funayama et al., 2017; Nogueira et 
Table III. Variables involved in insulin sensitivity during alcohol drinking in healthy humans.

\begin{tabular}{|c|c|c|}
\hline Influences on drinking & Effect on insulin sensitivity & References \\
\hline \multirow[t]{4}{*}{ Time of exposure } & $\begin{array}{l}\text { Acute alcohol consumption is not associated with increased } \\
\text { insulin sensitivity. }\end{array}$ & Flanagan et al., 2002 \\
\hline & $\begin{array}{l}\text { Chronic alcohol consumption not have effects on insulin } \\
\text { sensitivity. }\end{array}$ & Beulens et al., 2008 \\
\hline & $\begin{array}{l}\text { Chronic alcohol consumption was associated with an increased } \\
\text { risk of T2DM. }\end{array}$ & Funayama et al., 2017 \\
\hline & Chronic alcohol improves insulin levels & $\begin{array}{l}\text { Uribe et al., 2004; Nogueira et } \\
\text { al., } 2017\end{array}$ \\
\hline \multirow[t]{3}{*}{ Age } & Alcohol consumption improves insulin levels in adults. & $\begin{array}{l}\text { Uribe et al., 2004; Nogueira et } \\
\text { al., } 2017\end{array}$ \\
\hline & $\begin{array}{l}\text { Alcohol intake is not associated with changes on insulin } \\
\text { sensitivity in adults. }\end{array}$ & $\begin{array}{l}\text { Uribe et al., 2004; Nogueira et } \\
\text { al., } 2017\end{array}$ \\
\hline & $\begin{array}{l}\text { Alcohol consumption is associated with an increased risk of } \\
\text { T2DM in adults. }\end{array}$ & Funayama et al., 2017 \\
\hline \multirow[t]{3}{*}{ Dosage } & $\begin{array}{l}\text { Moderate alcohol consumption is } \mathrm{n} \text { ot associated with insulin } \\
\text { sensitivity. }\end{array}$ & $\begin{array}{l}\text { Flanagan et al., 2002; Beulens et } \\
\text { al., } 2008\end{array}$ \\
\hline & $\begin{array}{l}\text { Moderate to high alcohol consumption is associated with an } \\
\text { increased risk of T2DM. }\end{array}$ & Funayama et al., 2017 \\
\hline & $\begin{array}{l}\text { Moderate alcohol consumption has a beneficial effect on insulin } \\
\text { sensitivity. }\end{array}$ & $\begin{array}{l}\text { Uribe et al., 2004; Nogueira et } \\
\text { al., } 2017\end{array}$ \\
\hline \multirow[t]{3}{*}{ Ethnicity } & $\begin{array}{l}\text { Alcohol consumption has a beneficial effect on insulin sensitivity } \\
\text { of Latin people. }\end{array}$ & $\begin{array}{l}\text { Uribe et al., 2004; Nogueira et } \\
\text { al., } 2017\end{array}$ \\
\hline & $\begin{array}{l}\text { Alcohol consumption is not associated with increased insulin } \\
\text { sensitivity in Europeans. }\end{array}$ & $\begin{array}{l}\text { Flanagan et al., 2002; Beulens et } \\
\text { al., } 2008\end{array}$ \\
\hline & $\begin{array}{l}\text { Alcohol consumption is associated with an increased risk of } \\
\text { T2DM in Japanese people. }\end{array}$ & Funayama et al., 2017 \\
\hline \multirow[t]{3}{*}{ Alcohol type } & $\begin{array}{l}\text { Stolichnaya Vodka consumption is not associated with insulin } \\
\text { sensitivity. }\end{array}$ & Flanag an et al., 2002 \\
\hline & Beer consumption does not produce changes on insulin sensitivity. & Beulens et al., 2008 \\
\hline & Beer resulted in an increase in insulin concentrations. & Nogueira et al., 2017 \\
\hline Other results & No conclusions can be drawn about causality. & Goude et al., 2002 \\
\hline
\end{tabular}

T2DM: Type 2 diabetes.

al., 2017). A summary of included studies, and the populations and context in which they were conducted is shown in Table II.

\section{Description of included studies}

From the primary studies, two papers were conducted in Brazil, one in the United States, one in Sweden, one in Japan, one in United Kingdom and one in Netherlands. A total of seven original articles were analyzed. All papers collected and reported quantitative data - two papers collected data through randomized crossover design, four from cross-sectional study using interviews or food frequency questionnaire and one used a non-randomized study (Table II).

Six studies included just men participants and, one included both male and female participants (Nogueira et al.,
2014). Two studies were conducted in Latin people (Nogueira et al., 2014; Nogueira et al., 2017); three in allCaucasian population (Flanagan et al., 2002; Beulens et al., 2018; Goude et al.) one in white people (Uribe et al.) and one study in Japanese people (Funayama et al.). Details of alcohol consumption of study participants where available are shown in Table II. Three studies included some abstainers, including past drinkers (Flanagan et al., 2002; Uribe et al.; Funayama et al.). One study stated inclusion of non-drinkers (Beulens et al.), while one study appeared to include participants drinking at a range of levels (Nogueira et al., 2014), though this was sometimes not clearly reported (Goude et al.).

\section{Quality assessment}

Quality assessment results and assessment criteria of individual studies is shown in Table IV. Overall, quality of 
studies was generally high or moderate for internal and external validity, while one study rated as low for external validity (Nogueira et al., 2014).

\section{Relation between alcohol intake and insulin sensitivity}

Few studies describe the variables involved during alcohol intake, such as time of exposure, age, dose, ethnicity, or type of alcohol consumed; most of the findings related was widely to the effects on biochemical blood parameters, plasma insulin and plasma glucose.

While studies had different objectives, populations and context, some themes were consistently repeated across several studies (Table III). Of the main themes described below, none were solely identified in studies rated as lower quality - these issues were also raised in other higher quality studies. The possible guidelines to use alcohol intake on the improvement insulin sensitivity in humans are shown in Fig. 2.

Time of exposure. Period of alcohol feeding was indicated in almost all studies (Table III).

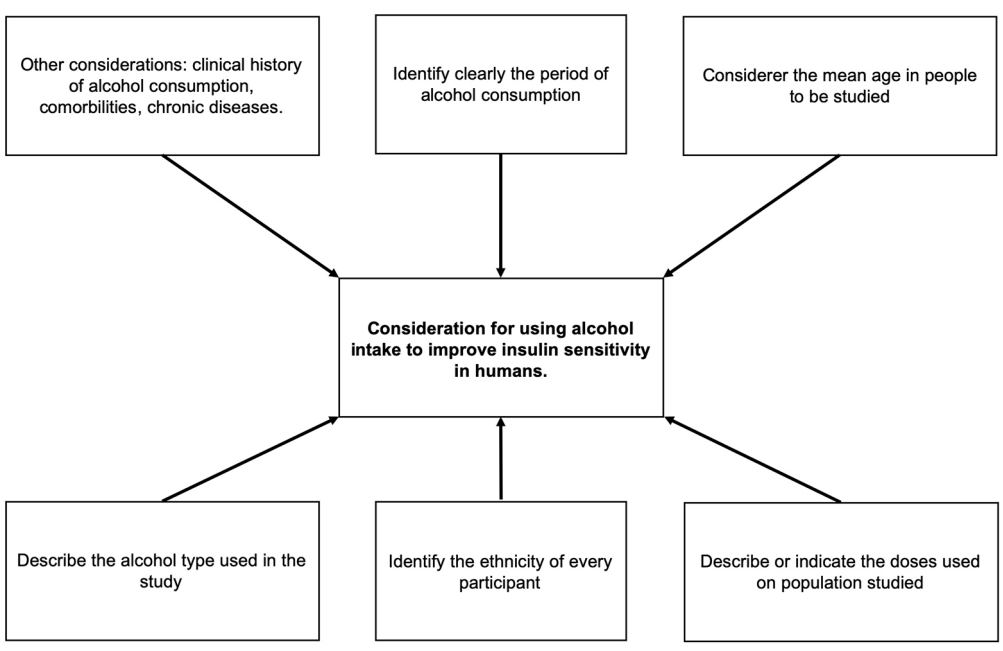

Fig. 2. Possible guidelines to use alcohol intake on the improvement insulin sensitivity in humans.

However, even if the time of alcohol exposure is not clearly described on it, this could be inferred from the information provided in each one, where just some of them have not expressly point it out (Goude et al.).

It was often used the specific time or the range of ethanol consumption to express the period exposure to alcohol (Uribe et al.; Funayama et al.; Beulens et al.). Although in some studies an established questionnaire was given to evaluate history of alcohol consumption and the period of consumption was not clearly given (Goude et al.).

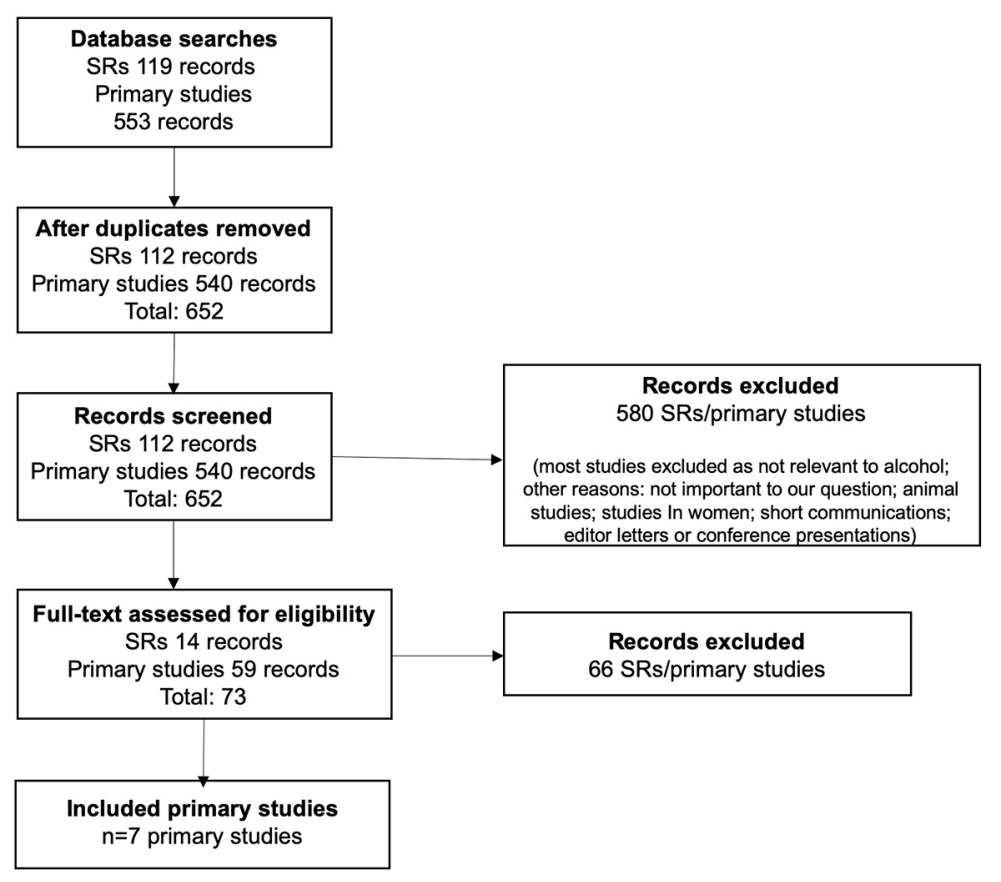

Fig. 1. PRISMA flow diagram.
Age. The beneficial effects of alcohol consumption on insulin levels have been shown in several studies. However, the effects of alcohol consumption depend on the age of the study population. For example, alcohol intake was not associated with changes on insulin sensitivity in adults between 21 to 41 years old (Flanagan et al.; 2002; Beulens et al.). Meanwhile, an improvement on insulin levels has been shown in adults between 26.5 - 57 years old (Nogueira et al., 2017; Uribe et al.). Funayama et al., has associated alcohol consumption with an increased risk of T2DM in adults over 25 years old.

Dosage. Epidemiological evidence suggests that alcohol intake is associated with T2DM. In this sense, the protective effect of moderate alcohol consumption on T2DM has been described through the enhancing effect of moderate alcohol drinking on insulin sensitivity observed in previous cross-sectional or epidemiological studies (Steyn et al., 2004; Uribe et al.; van de Wiel, 2004; Nogueira et al., 2017; Schroder, 
Table IV. Quality assessment for quantitative studies.

\begin{tabular}{|c|c|c|c|c|c|c|c|c|}
\hline & & $\begin{array}{l}\text { Nogueira } \text { et } \\
\text { al., } 2014\end{array}$ & $\begin{array}{l}\text { Flanag an } e t \\
\text { al., } 2002\end{array}$ & $\begin{array}{l}\text { Beulens et } \\
\text { al., } 2008\end{array}$ & $\begin{array}{l}\text { Funayama } e t \\
\text { al., } 2017\end{array}$ & $\begin{array}{l}\text { Goude } e t \\
\text { al., } 2002\end{array}$ & $\begin{array}{l}\text { Nogueira } e t \\
\text { al., } 2017\end{array}$ & $\begin{array}{l}\text { Uribe } e t \\
\text { al., } 2004\end{array}$ \\
\hline \multicolumn{2}{|l|}{ Study design } & $\begin{array}{l}\text { Cross- } \\
\text { sectional } \\
\text { study }\end{array}$ & $\begin{array}{l}\text { Randomized } \\
\text { controlled } \\
\text { trial }\end{array}$ & $\begin{array}{l}\text { Randomize } \\
\mathrm{d} \\
\text { controlled } \\
\text { trial }\end{array}$ & $\begin{array}{l}\text { Non- } \\
\text { randomized } \\
\text { controlled } \\
\text { trial }\end{array}$ & $\begin{array}{l}\text { Cross- } \\
\text { sectional } \\
\text { study }\end{array}$ & $\begin{array}{l}\text { Cross- } \\
\text { sectional } \\
\text { study }\end{array}$ & $\begin{array}{l}\text { Cross- } \\
\text { sectional } \\
\text { study }\end{array}$ \\
\hline \multirow[t]{3}{*}{ Population } & $\mathbf{1}$ & + & ++ & + & ++ & ++ & ++ & ++ \\
\hline & 2 & - & + & + & + & ++ & + & - \\
\hline & 3 & + & + & + & + & ++ & + & + \\
\hline \multirow{10}{*}{$\begin{array}{l}\text { Method of } \\
\text { allocation to } \\
\text { intervention } \\
\text { (or } \\
\text { comparison) }\end{array}$} & 4 & + & ++ & ++ & - & ++ & + & - \\
\hline & 5 & + & ++ & ++ & + & + & ++ & - \\
\hline & 6 & NR & NR & NR & NA & NA & NR & NR \\
\hline & 7 & - & NR & NR & - & - & NR & ++ \\
\hline & 8 & NR & NR & NR & - & NR & NR & NR \\
\hline & 9 & NR & NA & NA & NA & NA & NR & NA \\
\hline & 10 & NR & NA & NA & NA & NA & ++ & NA \\
\hline & 11 & NR & NA & NA & NA & NA & NR & NR \\
\hline & 12 & - & ++ & - & ++ & - & - & ++ \\
\hline & 13 & NA & NR & NA & NR & NA & NA & NR \\
\hline \multirow[t]{6}{*}{ Outcomes } & 14 & + & ++ & ++ & + & ++ & ++ & ++ \\
\hline & 15 & ++ & ++ & ++ & ++ & ++ & ++ & ++ \\
\hline & 16 & ++ & ++ & ++ & ++ & ++ & ++ & ++ \\
\hline & 17 & ++ & ++ & ++ & ++ & ++ & ++ & ++ \\
\hline & 18 & ++ & ++ & ++ & - & ++ & ++ & + \\
\hline & 19 & ++ & ++ & ++ & ++ & ++ & ++ & ++ \\
\hline \multirow[t]{6}{*}{ Analyses } & 20 & NA & ++ & ++ & NA & ++ & ++ & + \\
\hline & 21 & NR & NA & NA & NA & + & NR & NR \\
\hline & 22 & ++ & ++ & ++ & ++ & ++ & ++ & ++ \\
\hline & 23 & NR & NR & NR & NR & NR & NR & NR \\
\hline & 24 & ++ & ++ & ++ & ++ & ++ & ++ & ++ \\
\hline & 25 & ++ & NR & NR & NR & NR & NR & ++ \\
\hline \multirow[t]{2}{*}{ Summary } & 26 & + & ++ & ++ & + & ++ & ++ & + \\
\hline & 27 & - & + & + & + & ++ & + & + \\
\hline
\end{tabular}

Key to headings: Population 1. Is the source population or source area well described? 2. Is the eligible population or area representative of the source population or area? 3. Do the selected participants or areas represent the eligible population or area? Method of allocation to intervention (or comparison) 4. Allocation to intervention (or comparison). How was selection bias minimized? 5. Were interventions (and comparisons) well described and appropriate? 6. Was the allocation concealed? 7. Were participants or investigators blind to exposure and comparison? 8 . Was the exposure to the intervention and comparison adequate? 9. Was contamination acceptably now? 10. Were other interventions similar in both groups? 11 . Were all participants accounted for at study conclusion? 12. Did the setting reflect usual UK practice? 13. Did the intervention or control comparison reflect usual UK practices? Outcomes 14. Were outcome measure reliable? 15 . Were all outcome measurements complete? 16. Were all important outcomes assessed? 17 . Were outcomes relevant? 18. Were there similar follow-up times in exposure and comparison groups? 19. Was follow-up time meaningful? Analyses 20. Were exposure and comparison groups similar at baseline? If not, were these adjusted? 21. Was intention to treat (ITT) analysis conducted? 22. Was the study sufficiently powered to detect an intervention effect (if one exists)? 23. Were the estimates of effect size given or calculable 24. Were the analytical methods appropriate 25. Was the precision of intervention effects given or calculable? Were they meaningful? Summary 26. Are the study results inte rnally valid (i.e. unbiased)? 27. Are the findings generalizable to the source population (i.e. externally valid)? (National Institute for Health and Care Excellence (NICE) Methodology checklist: quantitative studies. https://www.nice.org.uk/process/pmg4/chapter/appendix-f-quality-appraisal-checklist-quantitative-intervention-studies). -: Indicates that sources of bias may persist; +: Indicates that either the answer to the checklist question is not clear from the way the study is reported, or that the study may not have addressed all potential sources of bias for that particular aspect of study design; ++: Indicates that for that aspect, the study has been designed or conducted in such a way as to minimize the risk of bias; NR: Not reported; NA: Not applicable.

2020). However, other research has found no relationship between moderate alcohol consumption and insulin sensitivity (Beulens et al.; Flanagan et al., 2002). Only one research described moderate to high alcohol consumption is associated with an increased risk of T2DM (Funayama et al.).

Ethnicity. The effects of alcohol intake and its relationship with insulin sensitivity were multiples depending on the ancestry of the studied population. In effect, alcohol intake seems to have a beneficial effect on insulin sensitivity in Latin People (Nogueira et al., 2017; Uribe et al.). Conversely, alcohol consumption has been associated with an increased risk of T2DM in Japanese people (Funayama et al.). Not relationship between alcohol consumption and insulin sensitivity has been described in Europeans (Flanagan et al., 2002; Beulens et al.). 
Alcohol type. The type of alcoholic beverage ingested had an effect on plasma alcohol concentration after alcohol consumption. In effect, the composition of the alcoholic beverage affected the plasma insulin and glucose levels obtaining highest results in people drinking beer (Nogueira $e t$ al., 2017). However, other authors have described not changes on insulin sensitivity after beer consumption (Flanagan et al., 2002). While, Stolichnaya Vodka consumption has not been associated with insulin sensitivity, too (Beulens et al.).

This systematic review collates and synthesizes evidence from seven quantitative studies relating alcohol intake and insulin sensitivity. Although there are systematic reviews that link alcohol consumption with insulin sensitivity, the mechanism or pathway are still unclear. Our review provides an update of possible mechanisms to involved on increase insulin sensitivity during alcohol intake, where the alcohol effect as insulin sensitizer depends of: body weight, body fat, time of exposure, age, dosage, ethnicity and alcohol type.

\section{Summary of key findings and interpretation}

Alcohol consumption may decrease the risk of T2DM by promoting insulin sensitivity (Davies et al., 2002). On this sense, Paulson et al. (2010) pointed out that alcohol intake increased leptin and adiponectin levels, suggesting that alcohol consumption may increase glucose catabolism promoting insulin sensitivity via leptin and adiponectin. Also, they provide evidence that alcohol may improve insulin sensitivity by upregulating anti-inflammatory genes, such IL-10 and Adrbk1, which proposes that alcohol might affect anti-inflammatory factors to stimulate insulin sensitivity.

It is important to note that the effects of alcohol on glucose metabolism are complex and the results of the effects of acute alcohol cannot be assumed to be the same as chronic effects. In this sense, some studies have pointing out that acute and chronic alcohol consumption could exacerbate the development of T2DM due to the antagonistic role in the elimination of glucose in peripheral tissues and the suppression of hepatic glucose production (Funayama et al.). Whereas other studies suggest that acute or moderate alcohol consumption are not associate with insulin sensitivity (Flanagan et al., 2002; Beulens et al.). These findings contrast with the results of previous epidemiological studies which suggest that moderate alcohol consumption is associated with decreased insulin resistance (Heaton, 1995; Kiechl et al.; Razay et al., 1992; Flanagan et al., 2000). This may reflect the short length -only 7 days- of this study. Suggested mechanisms for a link between ethanol and insulin resistance include long-term alterations in hepatic glucose metabolism with decreased hepatic gluconeogenesis (Villegas et al., 2004). A further crossover studies are therefore required with a longer period of alcohol consumption to confirm or refute the previous epidemiological findings.

Although the mechanisms for alcohol effects over insulin remains equivocal, several studies have reported a Uor J-shaped relationship between alcohol consumption and either insulin sensitivity or plasma insulin concentrations (Kiechl et al.; Lazarus et al.; Villegas et al.). During T2DM (non-insulin dependent diabetes) continues insulin production in the early phase of the disease; however, the body resists insulin's effect. Initially, resistance can be overcome by increasing insulin production. Eventually, the body can no longer produce enough insulin. A deficit in insulin secretion, coupled with the state of insulin resistance, leads to T2DM (Mauvais-Jarvis \& Kahn, 2000). In most patients, the disease develops over age 40 , where it is characterized by a reduction of insulin production plus resistance (DeFronzo, 1992). Moderate alcohol use has been demonstrated to have beneficial health effects across a spectrum of conditions, including insulin sensitivity and metabolic syndrome (Poli et al., 2013; Churilla et al., 2014). In effect, the consensus from a host of epidemiological studies is that is associated with reduced risk of T2DM (Steyn et al.; Uribe et al.; van de Wiel, 2004; Carlsson et al., 2005; Nogueira et al., 2017; Schroder). Specifically, with regard to metabolic parameters, moderate alcohol use in healthy subjects has been associated with lower plasma glucose and insulin concentrations following oral glucose administration, and improved insulin-mediated glucose uptake (Facchini et al.). This could be sustained by cellular mechanisms describe the liver plays an important role in improved insulin sensitivity during moderate alcohol consumption, leading to higher hepatic glycogen content, increased liver insulin receptor substrate-1, and protein kinase B phosphorylation (Tomie Furuya et al., 2005).

However, Funayama et al., has associated alcohol consumption with an increased risk T2DM in Japanese adults over 25 years old. This could due to in persons of East Asian ancestry, genetic variants to slower metabolism of alcohol and its metabolite acetaldehyde are much more common than in persons of European ancestry (Shin et al., 2017). Thus, the impact of alcohol consumption on the development of T2DM is likely to depend on patterns of alcohol consumption, sex, and ethnicity (Kawakita et al., 2016).

\section{Scope and limitations}

The goal of this study was to seek an explanation that would reconcile prior conflicting findings concerning the ability of moderate alcohol ingestion to improve insulin sensitivity. Most of the studies identified by this review were conducted in people drinking at a range of consumption levels. Specifically, it was to test the hypothesis that alcohol intake 
could enhance the insulin sensitivity in healthy people. Unfortunately, the results provide little support for this notion. At best, we could only discern a trend towards enhanced insulin sensitivity in the most of studies with significant improvement in those who had moderate alcohol consumption. In light of these data, it appears that moderate alcohol consumption, either as vodka or beer, did not significantly improve insulin sensitivity in healthy people.

The older population included in the review was people aged 60 years old. This age cut-off was chosen to reflect potential for onset earlier disease relating to metabolic syndrome. Most quantitative studies had fewer than 50 participants.

The type of alcoholic beverage ingested had an effect on the plasma alcohol concentration after the acute or chronic consumption of alcohol. However, the number of studies may have been too low to detect influences by dosage and duration. This paper updates the evidence between moderate alcohol ingestion and the relation with insulin sensitivity. In addition, it provides further details of the methods, analysis and synthesis to contribute the development of context sensitive interventions and policies to improve insulin sensitivity in healthy adults using alcohol.

\section{CONCLUSIONS}

Despite all the advances that have been made in clarifying effects caused by alcohol consumption, the future studies should clarify more efficiently the relationship between ethanol consumption and insulin sensitivity, taken care of time of exposure, age, dosage, ethnicity, and alcohol type in order to become to conclude right affirmations.

\section{SANDOVAL, C.; HERRERA, C.; SCHULZ, M. \& VÁSQUEZ,} B. Relación entre la ingesta de etanol y el metabolismo de la sensibilidad a la insulina en hombres sin comorbilidades: Una revisión sistemática. Int. J. Morphol., 39(3):829-838, 2021.

RESUMEN: La asociación del consumo de alcohol con la diabetes tipo 2 se ha explicado por una mayor sensibilidad a la insulina, efectos antiinflamatorios o efectos de la adiponectina. El objetivo fue establecer una relación coherente entre la ingesta de alcohol y la sensibilidad a la insulina. Se realizaron búsquedas en varias bases de datos (MEDLINE, EMBASE, Scopus y Web of Science) desde 1990 hasta abril de 2020 en busca de estudios en inglés, utilizando términos MeSH y palabras de textos relacionadas con el consumo de alcohol y la sensibilidad a la insulina. Protocolo registrado en PROSPERO CRD42020205107. Se analizaron un total de siete artículos originales, donde cuatro recopilaron datos a través de un estudio transversal, dos artículos con diseño cruzado aleatorizado y uno utilizó un estudio no aleatorizado. Se ha descrito el efecto protector del consumo moderado de alcohol sobre la diabetes tipo 2, donde se ha demostrado una mejora de los niveles de insulina en adultos entre 26,5 y 57 años. Nuestra investigación muestra que los efectos del alcohol sobre los niveles de insulina en sangre pueden variar según el tipo de bebida alcohólica ingerida; y que la ingesta de alcohol aumenta los niveles de leptina y adiponectina, lo que sugiere que el consumo de alcohol puede aumentar el catabolismo de la glucosa promoviendo la sensibilidad a la insulina a través de la leptina y la adiponectina. Sin embargo, los estudios originales deben considerar el tiempo de exposición, la edad, la dosis, el origen étnico y el tipo de alcohol para concluir afirmaciones correctas.

PALABRAS CLAVE: Consumo de alcohol; Diabetes mellitus; Epidemiología; Insulina; Humanos.

\section{REFERENCES}

Arias, D. R. Reacciones fisiológicas y neuroquímicas del alcoholismo. Diversitas, 1(2):138-47, 2005.

Beulens, J. W. J.; de Zoete, E. C.; Kok, F. J.; Schaafsma, G. \& Hendriks, H. F. J. Effect of moderate alcohol consumption on adipokines and insulin sensitivity in lean and overweight men: a diet intervention study. Eur. J. Clin. Nutr., 62:1098-105, 2008.

Buemann, B.; Dyerberg, J. \& Astrup, A. Alcohol drinking and cardiac risk. Nutr. Res. Rev., 15:91-121, 2002.

Carlsson, S.; Hammar, N. \& Grill, V. Alcohol consumption and type 2 diabetes meta-analysis of epidemiological studies indicates a U-shaped relationship. Diabetologia, 48:1051-4, 2005.

Churilla, J. R.; Johnson, T. M.; Curls, R.; Richardson, M. R.; Boyer, W. R., Devore, S. R. \& Alnojeidi, A. H. Association between alcohol consumption patterns and metabolic syndrome. Diabetol. Metab. Syndr., 8:119-23, 2014.

Criqui, M. H. Alcohol and coronary heart disease: consistent relationship and public health implications. Clin. Chim. Acta, 246:51-7, 1996.

Davies, M. J.; Baer, D. J.; Judd, J. T.; Brown, E. D.; Campbell, W. S. \& Taylor, P. R. Effects of moderate alcohol intake on fasting insulin and glucose concentrations and insulin sensitivity in postmenopausal women: a randomized controlled trial. JAMA., 287(19):2559-62, 2002.

DeFronzo, R. A. Pathogenesis of type 2 (non-insulin dependent) diabetes mellitus: a balanced overview. Diabetologia, 35(4):389-97, 1992.

Doll, R.; Peto, R.; Hall, E.; Wheatley, K. \& Gray, R. Mortality in relation to consumption of alcohol: 13 years' observations on male British doctors. BMJ., 309(6959):911-8, 1994

Doll, R. One for the heart. BMJ., 315:1664-8, 1997.

Facchini, F.; Chen, Y. D. \& Reaven, G. M. Light-to-moderate alcohol intake is associated with enhanced insulin sensitivity. Diabetes Care, 17(2):115-9, 1997.

Flanagan, D. E.; Moore, V. M.; Godsland, I. F.; Cockington, R. A.; Robinson, J. S. \& Phillips, D. I. Alcohol consumption and insulin resistance in young adults. Eur. J. Clin. Invest., 30(4):297-301, 2000.

Flanagan, D. E. H.; Pratt, E.; Murphy, J.; Vaile, J. C.; Petley, G. W.; Godsland, I. F. \& Kerr, D. Alcohol consumption alters insulin secretion and cardiac autonomic activity. Eur. J. Clin. Invest., 32(3):187-92, 2002.

Funayama, T.; Tamura, Y.; Takeno, K.; Kawaguchi, M.; Kakehi, S.; Watanabe, T.; Furukawa, Y.; Kaga, H.; Yamamoto, R.; Kanazawa, A.; Fujitani, Y.; Kawamori, R. \& Watada, H. Effects of alcohol abstinence on glucose metabolism in Japanese men with elevated fasting glucose: A pilot study. Sci. Rep., 7(1):40277, 2017.

Furuya, D. T.; Binsack, R. \& Machado, U. F. Low ethanol consumption increases insulin sensitivity in Wistar rats. Braz. J. Med. Biol. Res., 36(1):125-30, 2003. 
García Gutiérrez, E.; Lima Mompó, G.; Aldana Vilas, L.; Casanova Carrillo, P. \& Feliciano Álvarez, V. Alcoholismo y sociedad, tendencias actuales. Rev. Cuba. Med. Mil., 33(3):1-10, 2004.

Goude, D.; Fagerberg, B. \& Hulthe, H. Alcohol consumption, the metabolic syndrome and insulin resistance in 58-year-old clinically healthy men (AIR study). Clin. Sci., 102(3):345-52, 2002.

Kannel, W. B. \& Ellison, R. C. Alcohol and coronary heart disease: the evidence for a protective effect. Clin. Chim. Acta, 246(1-2):59-76, 1996.

Kawakita, D.; Oze, I.; Hosono, S.; Ito, H.; Watanabe, M.; Yatabe, Y.; Hasegawa, Y.; Murakami, S.; Tanaka, H. \& Matsuo, K. Prognostic value of drinking status and aldehyde dehydrogenase 2 polymorphism in patients with head and neck squamous cell carcinoma. J. Epidemiol., 26(6):292-9, 2016.

Kiechl, S.; Willeit, J.; Poewe, W.; Egger, G.; Oberhollenzer, F.; Muggeo, M. $\&$ Bonora, E. Insulin sensitivity and regular alcohol consumption: large, prospective, cross sectional population study (Bruneck study). BMJ., 313(7064):1040-4, 1996.

Kim, Y. I. Folate and carcinogenesis: evidence, mechanisms, and implications. J. Nutr. Biochem., 10(2):66-88, 1999.

Kim, Y. I. Folate and DNA methylation: a mechanistic link between folate deficiency and colorectal cancer? Cancer Epidemiol. Biomarkers Prev., 13(4):511-9, 2004.

Klatsky, A. L.; Armstrong, M. A. \& Friedman, G. D. Alcohol and mortality. Ann. Intern. Med., 117(8):646-54, 1992.

Lazarus, R.; Sparrow, D. \& Weiss, S. T. Alcohol intake and insulin levels: The normative aging study. Am. J. Epidemiol., 145(10):909-16, 1997.

Mauvais-Jarvis, F. \& Kahn, C. R. Understanding the pathogenesis and treatment of insulin resistance and type 2 diabetes mellitus: what can we learn from transgenic and knockout mice? Diabetes Metab., 26(6):43348, 2000.

Moher, D.; Liberati, A.; Tetzlaff, J. \& Altman, D. G. Prisma Group. Preferred reporting items for systematic reviews and meta-analyses: The PRISMA Statement. PLoS Med., 6(7):e1000097, 2009.

Mukamal, K. J. Alcohol consumption and abnormalities of brain structure and vasculature. Am. J. Geriatr. Cardiol., 13(1):22-8, 2004.

National Institute for Health and Care Excellence: Appendix F Quality appraisal checklist - quantitative intervention studies. In Methods for the development of NICE public health guidance. London, UK: National Institute for Health and Care Excellence. 2012. Available in: https:// www.nice.org.uk/process/pmg4/chapter/about-this-document

Nogueira, L. C.; Couri, S.; Trugo, N. F. \& Lollo, P. C. B. The effect of different alcoholic beverages on blood alcohol levels, plasma insulin and plasma glucose in humans. Food Chem., 158:527-33, 2014.

Nogueira, L. C.; do Rio, R. F.; Pollo, P. C. B. \& Ferreira, I. M. P. L. V. O. Moderate Alcoholic Beer Consumption: The Effects on the Lipid Profile and Insulin Sensitivity of Adult Men. J. Food Sci., 82(2):1720-5, 2017.

Paulson, Q. X.; Hong, J.; Holcomb, V. B. \& Nunez, N. P. Effects of body weight and alcohol consumption on insulin sensitivity. Nutr. J., 9:14, 2010.

Poli, A.; Marangoni, F.; Avogaro, A.; Barba, G.; Bellentani, S.; Bucci, M.; Cambieri, R.; Catapano, A. L.; Costanzo, S.; Cricelli, C.; de Gaetano, G.; Di Castelnuovo, A.; Faggiano, P.; Fattirolli, F.; Fontana, L.; Forlani, G.; Frattini, S.; Giacco, R.; La Vecchia, C.; Lazzaretto, L.; Loffredo, L.; Lucchin, L.; Marelli, G.; Marrocco, W.; Minisola, S.; Musicco, M.; Novo, S.; Nozzoli, C.; Pelucchi, C.; Perri, L.; Pieralli, F.; Rizzoni, D.; Sterzi, R.; Vettor, R.; Violi, F. \& Visioli, F. Moderate alcohol use and health: a consensus document. Nutr. Metab. Cardiovas. Dis., 23(6):487-504, 2013.

Razay, G.; Heaton, K. W. \& Bolton, C. H. \& Hughes, A. O. Alcohol consumption and its relation to cardiovascular risk factors in British women. BMJ., 304:80-83, 1992.

Rimm, E. B.; Giovannucci, E. L.; Willett, W. C.; Colditz, G. A.; Ascherio, A.; Rosner, B. \& Stampfer, M. J. Prospective study of alcohol consumption and risk of coronary disease in men. Lancet, 338(8765):464-8, 1991.

Sandoval, C.; Herrera, C.; Schulz, M. \& Vásquez, B. Relationship between ethanol intake and insulin sensitivity metabolism in men with no comorbidities: A systematic review. PROSPERO CRD42020205107, 2020. Available from: https://www.crd.york.ac.uk/prospero/ display_record.php?ID=CRD42020205107
Sandoval, C.; Vásquez, B.; Mandarim-de-Lacerda, C. \& del Sol, M. Ethanol intake and toxicity: In search of new treatments. Int. J. Morphol., 35(3):942-9, 2017.

Schrieks, I. C.; Heil, A. L.; Hendriks, H. F.; Mukamal, K. J. \& Beulens, J. W. The effect of alcohol consumption on insulin sensitivity and glycemic status: a systematic review and meta-analysis of intervention studies. Diabetes Care, 38(4):723-32, 2015.

Schroder, H. Protective mechanisms of the Mediterranean diet in obesity and type 2 diabetes. J. Nutr. Biochem., 18(8):149-60, 2020.

Shin, M. J.; Cho, Y. \& Davey Smith, G. Alcohol consumption, aldehyde dehydrogenase 2 gene polymorphisms, and cardiovascular health in Korea. Yonsei Med. J., 58(4):689-96, 2017.

Steyn, N. P.; Mann, J.; Bennett, P. H.; Temple, N.; Zimmet, P.; Tuomilehto, J.; Lindström, J. \& Louheranta, A. Diet, nutrition and the prevention of type 2 diabetes. Public Health Nutr., 7(1A):147-65, 2004.

Tomie Furuya, D.; Binsack, R.; Onishi, M. E.; Monteiro Seraphim, P. \& Fabres Machado, U. Low ethanol consumption induces enhancement of insulin sensitivity in liver of normal rats. Life Sci., 77(15):1813-24, 2005.

Uribe, L. A.; Bacchetti, P.; Gelman, N.; Burchard, E.; Fitch, M.; Hellerstein, M. \& Khalili, M. Impact of Moderate Alcohol Discontinuation on Insulin Action and Secretion in Latinos With and Without Hepatitis C. Alcohol Clin. Exp. Res., 42(3):492-9, 2004.

van de Wiel, A. Alcohol and insulin sensitivity. Neth. J. Med., 52(3):91-4, 1998.

van de Wiel, A. Diabetes mellitus and alcohol. Diabetes Metab. Res. Rev., 20(4):263-7, 2004.

Villegas, R.; Salim, A.; O’Halloran, D. \& Perry, I. J. Alcohol intake and insulin resistance. A cross-sectional study. Nutr. Metab. Cardiovas. Dis., 14(5):233-40, 2004.

Witt, H.; Apte, M. V.; Keim, V. \& Wilson, J. S. Chronic pancreatitis: challenges and advances in pathogenesis, genetics, diagnosis, and therapy. Gastroenterology, 132(4):1557-73, 2007.

World Health Organization. Alcohol. Descriptive Note $N^{\circ} 349$. NY, USA: World Health Organization, 2011.

Yokoyama, H. Beneficial effects of ethanol consumption on insulin resistance are only applicable to subjects without obesity or insulin resistance; drinking is not necessarily a remedy for metabolic syndrome. Int. J. Environ. Res. Public Health, 8(7):3019-31, 2011.

Corresponding author:

Dr. Cristian Sandoval

Departmento de Ciencias Preclínicas

Facultad de Medicina

Universidad de La Frontera

Avenida Francisco Salazar 01145

Temuco

CHILE

E-mail: cristian.sandoval@ufrontera.cl

Received: 09-03-2021

Accepted: 29-03-2021 